\title{
Tau Triggers Tear Secretion by Interacting with Muscarinic Acetylcholine Receptors in New Zealand White Rabbits
}

\author{
Alejandro Martinez-Aguila ${ }^{\mathrm{a}}$, Begoña Fonseca ${ }^{\mathrm{a}}$, Felix Hernandez ${ }^{\mathrm{b}}$, Miguel Díaz-Hernandez $^{\mathrm{c}, \mathrm{d}, *}$, \\ Jesús Avila ${ }^{\mathrm{b}}$ and Jesus Pintor ${ }^{\mathrm{a}, *}$ \\ ${ }^{a}$ Departamento de Bioquímica y Biología molecular IV, Facultad de Óptica, Universidad Complutense de Madrid, \\ Madrid, Spain \\ ${ }^{\mathrm{b}}$ Centro de Biología Molecular "Severo Ochoa", CSIC-Universidad Autónoma de Madrid, CIBERNET, Madrid, \\ Spain \\ ${ }^{\mathrm{c}}$ Departamento de Bioquímica y Biología Molecular IV, Facultad de Veterinaria, Universidad Complutense de \\ Madrid, Madrid, Spain \\ ${ }^{\mathrm{d}}$ Instituto de Investigación Sanitaria del Hospital Clínico San Carlos, Madrid, Spain
}

Accepted 5 January 2014

\begin{abstract}
In recent years, in vitro experiments have shown that the spread of Alzheimer's disease is caused by a non-conventional activation of muscarinic receptors by dephosphorylated extracellular tau protein. However, so far, in vivo data to support this hypothesis has not been obtained. The eye provides a good model where cholinergic (muscarinic) transmission can be analyzed. The role of muscarinic receptors in the stimulation of lacrimal gland secretion has already been described, and it has been suggested that acetylcholine is the main transmitter controlling tear secretion. In this project, we have studied the interaction between tau and muscarinic receptors by analyzing tear secretion in the eyes of white rabbits. Our results show that tau protein increases tear secretion by $47.2 \%$ in a similar way to a muscarinic receptor agonist carbachol (84.3\%). The use of muscarinic antagonists indicated that tau interacts with M1 and mainly M3 muscarinic receptors. In summary, tau can bind muscarinic receptors in vivo and this may explain the spread of the pathology.
\end{abstract}

Keywords: Alzheimer's disease, muscarinic receptors, tau, tear secretion

\section{INTRODUCTION}

Alzheimer's disease (AD) is a neurodegenerative disease characterized by the presence of senile plaques and neurofibrillary tangles that are aggregates of paired

\footnotetext{
*Correspondence to: Miguel Díaz-Hernandez, Departamento de Bioquimica y Biología Molecular IV, Facultad Veterinaria, Universidad Complutense de Madrid, Av. Puerta de Hierro s/n, 28040 Madrid, Spain. Tel.: +34 91 3944068; Fax: +34 91 3943909; E-mail: migueldiaz@vet.ucm.es; Jesus Pintor, Departamento de Bioquimica y Biología Molecular IV, Facultad Optica y Optometría, Universidad Complutense de Madrid, C/Arcos de Jalon 118, 28037 Madrid, Spain. Tel.: +34 91 3946859; Fax: +34 91 3946885; E-mail: jpintor@vet.ucm.es.
}

helical filaments, the main component of which is tau protein. One of the main features of this pathology is a huge death of cholinergic (bearing nicotine or muscarinic receptors) neurons [1]. Upon neuronal death, intracellular tau could be released to the extracellular medium and become toxic [2, 3]. Also, the presence of extracellular tau in physiological fluids such as the cerebrospinal fluid of $\mathrm{AD}$ patients could be the consequence of previous cell death [4]. Nevertheless, there is evidence to indicate that tau might be released by mechanisms that do not imply cell death [5-13]. Indeed, it has been shown that extracellular tau can induce more tau release by a mechanism that involves the participation of muscarinic acetylcholine receptors. 
This would not only implies that cell death may be the cause of tau spreading from cell to cell, through muscarinic receptors, but also, in the absence of cell death, that the progression of tau pathology could take place by a mechanism involving the binding of tau to muscarinic receptors. Nevertheless, all the studies investigating the possible interactions between tau and muscarinic receptors have been performed in vitro with little or no information between the real interactions of both proteins in vivo.

The eye, and in particular tear secretion, provides an interesting and elegant model where cholinergic transmission modulation can be studied. The control of tear production is carried out by the autonomic nervous system, and the stimulation of these nerves excites lacrimal glands, promoting secretion of lacrimal electrolytes, water, and proteins.

Although both the parasympathetic and the sympathetic nerves innervate the lacrimal gland, the parasympathetic system predominates, both anatomically and functionally [14-17]. In this sense the most relevant parasympathetic neurotransmitters regulating tear secretion are acetylcholine and VIP. These agonists are all stimulatory and can activate different signaling pathways [18].

In this sense, the use of cholinergic agents can induce or inhibit tear production. As an example, intra-arterial or intraperitoneal systemic administration of acetylcholine, pilocarpine, or other cholinergic agonists stimulates lacrimal gland protein and fluid secretion measured from cannulated lacrimal gland excretory duct of anesthetized rabbits [19-25]. Having said that, the effect of muscarinic antagonists suggests a major role for parasympathetic nerves in stimulation of lacrimal gland secretion since the systemic administration of the muscarinic cholinergic antagonist scopolamine, for instance, produces dry eye in mice [26]. Altogether this indicates that acetylcholine is the main transmitter controlling tear secretion.

Since it has been suggested that there is interaction between tau and muscarinic receptors in some in vitro models, but as this has not been fully elucidated in vivo, the present experimental work shows how tau can modulate tear secretion in vivo and how this process is mediated by its interaction with muscarinic acetylcholine receptors.

\section{MATERIALS AND METHODS}

\section{Animals}

24 male New Zealand white rabbits $(2.5 \pm 0.5 \mathrm{~kg})$ were used throughout all the experimentation. The ani- mals were kept in individual cages with free access to food and water. All the protocols described here adhere to the ARVO Statement for the Use of Animals in Ophthalmology and Vision Research, and the experiments were carried out in accordance with the principles of the European Communities Council Directive (86/609/EEC).

\section{Compounds and solutions}

Carbachol (carbamylcholine), pirenzepine, and galamine were purchased from Sigma (St. Louis, USA). 4-DAMP was purchased from Tocris (Minneapolis, USA). All the other reagents were from Merck (Darmstadt, Germany).

The recombinant unphosphorylated human tau isoform (tau42) containing $2 \mathrm{~N}$-terminal inserts and 4 microtubule binding repeats were isolated as previously described [27].

Hyperphosphorylated tau was purified from an insect cell culture infected with baculovirusexpressing human tau42 protein [28]. Tau peptide comprising the following sequence EIVYKSPVVSGDTSPRH, residues 391 to 407 (nomenclature of the largest tau isoform), present at the C-terminal region of the protein, was synthesized and purified, as previously described [29].

\section{Tear volume measurements}

Tear secretion was measured by using the Schirmer I test. The tear collection was always performed according to Van Bijsterveld criteria [30]. The Schirmer strip was placed on the temporal tarsal conjunctiva of the lower lid for $5 \mathrm{~min}$.

Control experiments were performed by applying $10 \mu \mathrm{l}$ of saline solution $(\mathrm{NaCl} 0.9 \%)$ and $5 \mathrm{~min}$ after that, the Schirmer strip was applied in the rabbit's lower lid for $5 \mathrm{~min}$. When the experiments were performed, the same volume of the desired compound at the concentration indicated in each case was applied and $5 \mathrm{~min}$ after the instillation the Schirmer strip was applied for $5 \mathrm{~min}$ as previously indicated. Tear secretion in each case was measured as the length of the wet strip (in $\mathrm{mm})$.

\section{Agonist studies}

Single dose experiments designed to study the timecourse of the tear secretion process were performed by adding carbamylcholine (carbachol, $100 \mu \mathrm{M}$ ), tau, tau peptide, or phospho tau (all at $1 \mu \mathrm{M}$ ) in a final 
volume of $10 \mu \mathrm{L}$ topically on the rabbit ocular surface. Contralateral eye received the same volume of vehicle (control). In order to see whether carbachol and tau were sharing the same receptors, carbachol $(100 \mu \mathrm{M})$ was applied and $15 \mathrm{~min}$ later $1 \mu \mathrm{M}$ tau was added.

Carbachol, tau, and the peptide of tau were tried at several concentrations ranging from $10^{-9} \mathrm{M}$ to $10^{-3} \mathrm{M}$ in order to obtain the corresponding concentrationresponse curves relating the dose of these agonists to the volume of tear production.

\section{Antagonist studies}

To study the effect of different antagonists in the inhibition of tear secretion produced by tau, the antagonists were tested alone (in vehicle) or $30 \mathrm{~min}$ before the application of tau $1 \mu \mathrm{M}(10 \mu \mathrm{L}) .5 \mathrm{~min}$ after that, the Schirmer strip was applied in the rabbit's lower lid for $5 \mathrm{~min}$.

As with the agonists, the ability of the antagonists was checked by assaying them at different concentrations. For these studies, the concentration of tau was fixed at $1 \mu \mathrm{M}(10 \mu \mathrm{L})$, and graded doses of pirenzepine, galamine, and 4-DAMP were tested from $10^{-8} \mathrm{M}$ to $10^{-4} \mathrm{M}$ to generate a family of curves to obtain the corresponding $\mathrm{pA}_{2}$ and $\mathrm{IC}_{50}$ values.

\section{Statistical analysis}

All data are presented as the mean \pm S.E.M. Statistical differences between treatments were calculated using ANOVA test. Plotting and fitting were carried out by GraphPad Prism 5 computer program (GraphPad Software).

\section{RESULTS}

The effect of tau and carbachol on tear secretion
in New Zealand white rabbits

The protein tau was tested at a single concentration of $1 \mu \mathrm{M}(10 \mu \mathrm{L})$. Its application increased tear secretion $47.62 \pm 9.12 \%$ over the basal tear secretion. Previously, it was indicated that a tau peptide containing the residues $390-423$ of the molecule is sufficient to interact with M1/M3 muscarinic receptors present in neuronal cells and that the interaction of that tau peptide with the cell receptors promotes the same effect as the addition of the whole tau molecule [3].

So we tested to see if the selected peptide of the protein tau $(1 \mu \mathrm{M} 10 \mu \mathrm{L})$ had the same effect, and found that upon addition of tau peptide 390-423, a similar effect to that observed for the whole tau molecule was shown by increasing tear secretion $50.00 \pm 7.14 \%$ $(n=8)$.

On the contrary, phosphorylated tau did not have any effect in tear secretion (Fig. 1A). Concerning the maximal effects for tau and its peptide, tau peptide presented a peak in tear secretion at $5 \mathrm{~min}$ and it continued at $35 \mathrm{~min}$, while the tau protein had no effect at $35 \mathrm{~min}$ (Fig. 1B).

Carbachol, the long lasting analogue of the naturally occurring transmitter acetylcholine, was assayed in order to see its effects on tear secretion. As shown in Fig. 1A, a single dose of $10 \mu \mathrm{L}(100 \mu \mathrm{M})$ carbachol induced a peak in tear secretion of $84.31 \pm 10.38 \%$ over basal tear secretion ( $10 \mu \mathrm{L}$ vehicle, $\mathrm{NaCl} 0.9 \%)$ whose maximal effect was detected $20 \mathrm{~min}$ after the application of the substance (Fig. $1 \mathrm{~B}, n=8$ ).
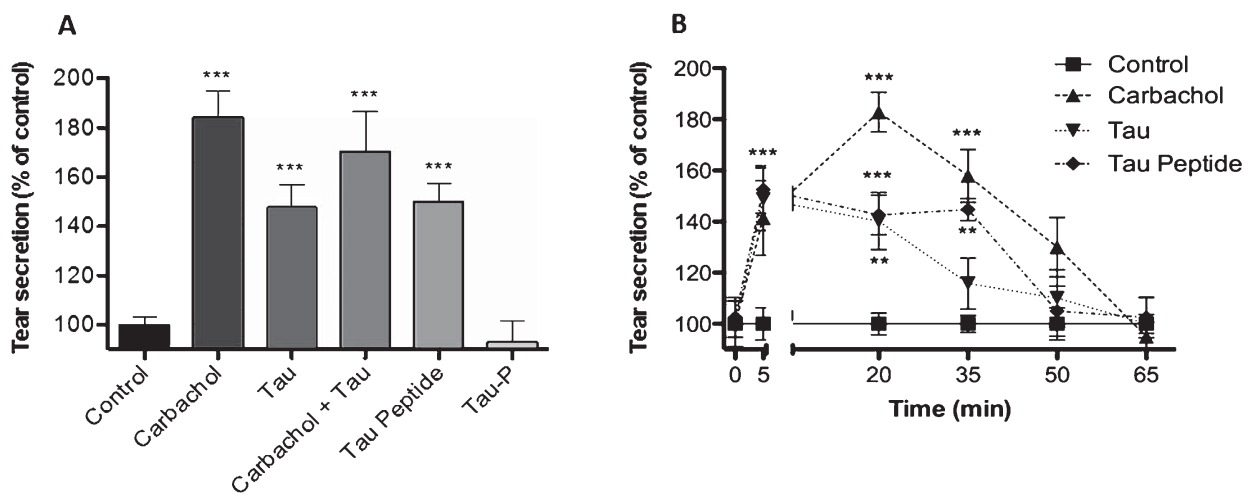

Fig. 1. Effect of carbachol, tau, tau peptide, and phosphorylated tau in rabbit tear secretion. A)Maximal effect of carbachol (100 $\mu \mathrm{M})$, tau ( $1 \mu \mathrm{M})$, carbachol $(100 \mu \mathrm{M})+\operatorname{tau}(1 \mu \mathrm{M})$, tau peptide $(1 \mu \mathrm{M})$, and phosphorylated tau $(0.5 \mu \mathrm{M})$. $100 \%$ represents tear secretion before application of any drug (i.e., at $\left.\mathrm{t}_{0}\right)$. B) Time-course of carbachol $(100 \mu \mathrm{M})$, tau $(1 \mu \mathrm{M})$, and tau peptide $(1 \mu \mathrm{M})$. Values represent the mean \pm s.e.m of eight independent experiments. ${ }^{*} p<0.01, * * * p<0.001$, with respect to control levels (ANOVA tests). 


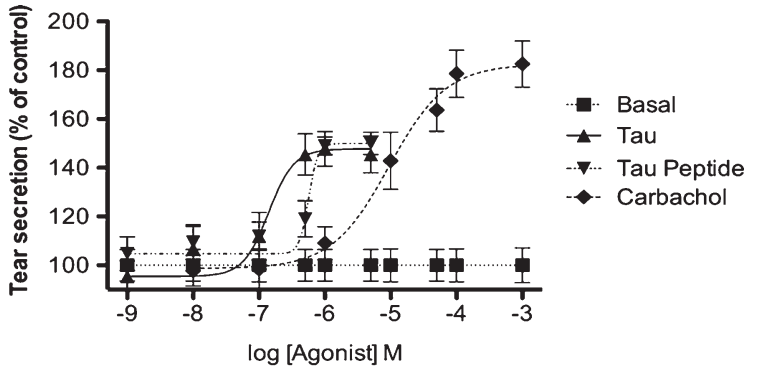

Fig. 2. Concentration-response course for carbachol, tau, and tau peptide. Graded doses of compounds were applied as described in methods. The maximal increased in tear secretion due to carbachol, tau, and tau peptide were $84.3 \pm 10.4 \%, 47.6 \pm 9.1 \%$, and $50.0 \pm 7.1 \%$, respectively. Values represent the mean \pm s.e.m of eight independent experiments. ${ }^{*} p<0.05$, ** $p<0.01$, *** $p<0.001$, with respect to control levels (Two-way ANOVA test with Bonferroni posttests).

In order to study if both carbachol and tau were acting via the same receptors, these compounds were applied and its possible additive effect analyzed. As can be seen in Fig. 1A, the addition of both substances did not produce an increase in tear secretion, indicating that they may act via the same receptor.

\section{Dose-response behavior for tau, its peptide, and carbachol on tear secretion}

Tau and its peptide were tested in a different range of concentrations (from $10^{-9} \mathrm{M}$ to $10^{-5} \mathrm{M}$ ) to fully investigate the effect of those peptides on tear secretion. As a consequence of this concentration-response analysis, it was possible to obtain a sigmoidal curve for each of them with $\mathrm{pD}_{2}$ values of $6.88 \pm 0.12$ and $6.27 \pm 0.09$, for tau and the peptide of tau, which were equivalent to $\mathrm{EC}_{50} \mathrm{~s}$ of 0.13 and $0.54 \mu \mathrm{M}$, respectively $(n=8)$ (Fig. 2). Both tau and its peptide were able to produce a maximal tear secretion of $149.45 \pm 9.12 \%$ and $152.00 \pm 9.42 \%$ at $10^{-6} \mathrm{M}$, respectively $(n=8)$, with no statistical differences between them.

When carbachol was tested in a broad range of concentrations (from $10^{-8} \mathrm{M}$ to $10^{-3} \mathrm{M}$ ) in order to see the concentration response behavior, it was possible to obtain a sigmoid dose-response curve. As can be seen in Fig. 2, carbachol sigmoidal curve obtained presented a $\mathrm{pD}_{2}$ value of $5.03 \pm 0.09$ which was equivalent to an $\mathrm{EC}_{50}$ of $9.43 \mu \mathrm{M}(n=8)$. The maximal tear secretion depicted by carbachol was $186.45 \pm 11.77 \%$, at $10^{-3} \mathrm{M}(n=8)$, this value being significantly higher than the ones obtained by tau and tau peptide (Fig. 2).

\section{Antagonist studies}

We measured the effect of tau in the presence of single doses of muscarinic antagonists in order to see whether or not there was a connection between tau and muscarinic receptors. The antagonists were tested in their ability to modify basal tear secretion by themselves. As can be seen in Fig. 3A, the only one able to produce a significant reduction in the basal tear production was the M3 antagonist 4-DAMP. This compound was able to reduce basal tear secretion by about $11 \%$ when compared to control $(n=4)$.

A concentration of $1 \mu \mathrm{M}$ tau produced an increase in tear secretion of $147.62 \pm 9.12 \%$ above basal tear secretion value (basal 100\%). Under these stimulated conditions, the effect of tau was challenged by means of several muscarinic receptor antagonists. In this sense, tear secretion was inhibited to $102.66 \pm 4.09 \%$ in case of pirenzepine (M1 antagonist), $112.08 \pm 6.36 \%$ with galamine (M2 antagonist), and $95.48 \pm 11.46 \%$ with 4-DAMP (M3 antagonist) (Fig. 3A).

Since these studies were only performed at single muscarinic antagonist concentrations, which may not reflect the real antagonistic properties of these agents, all the antagonists were tested again in a broad range of concentrations, from $10^{-8} \mathrm{M}$ to $10^{-4} \mathrm{M}$ in order to see the concentration response behavior. As shown in Fig. 3B, pirenzepine, galamine, and 4-DAMP revealed $\mathrm{pA}_{2}$ values of $6.17 \pm 0.09,5.38 \pm 0.18$, and $5.83 \pm 0.02$, respectively, which were equivalent to $\mathrm{IC}_{50}$ values of $0.69,4.18$, and $1.48 \mu \mathrm{M}$, respectively $(n=8)$.

Concerning the maximal inhibitory effect produced by the antagonists, it is important to emphasize that 4-DAMP was able to block $100 \%$ of the tear secretion triggered by tau, while galamine and pirenzepine were unable to completely block the tearing induced by tau (Fig. 3B).

\section{DISCUSSION}

In the present experimental work, we have found that human tau protein or its peptide, containing residues 390-423, are acting as agonists of muscarinic receptors $\mathrm{M} 1 / \mathrm{M} 3$, and that they can increase tear secretion on rabbits. Since tau peptide with the residues 390-423 of the molecule appears to be sufficient for that increase, we have looked at the sequence of rabbit tau and we found that such sequence was identical in rabbit and human tau. Those tau residues contain some residues that could be modified by phosphorylation and the tau 
A

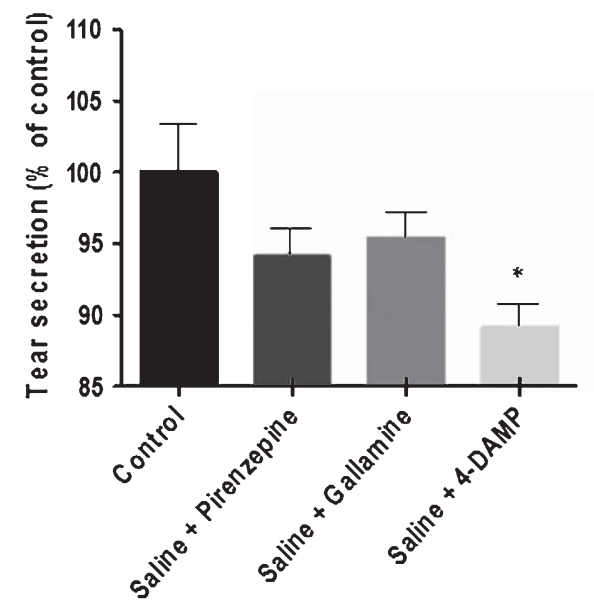

B

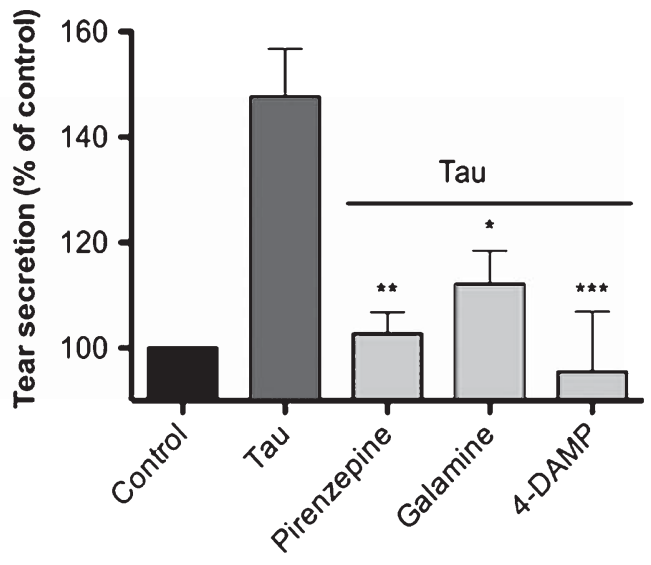

C

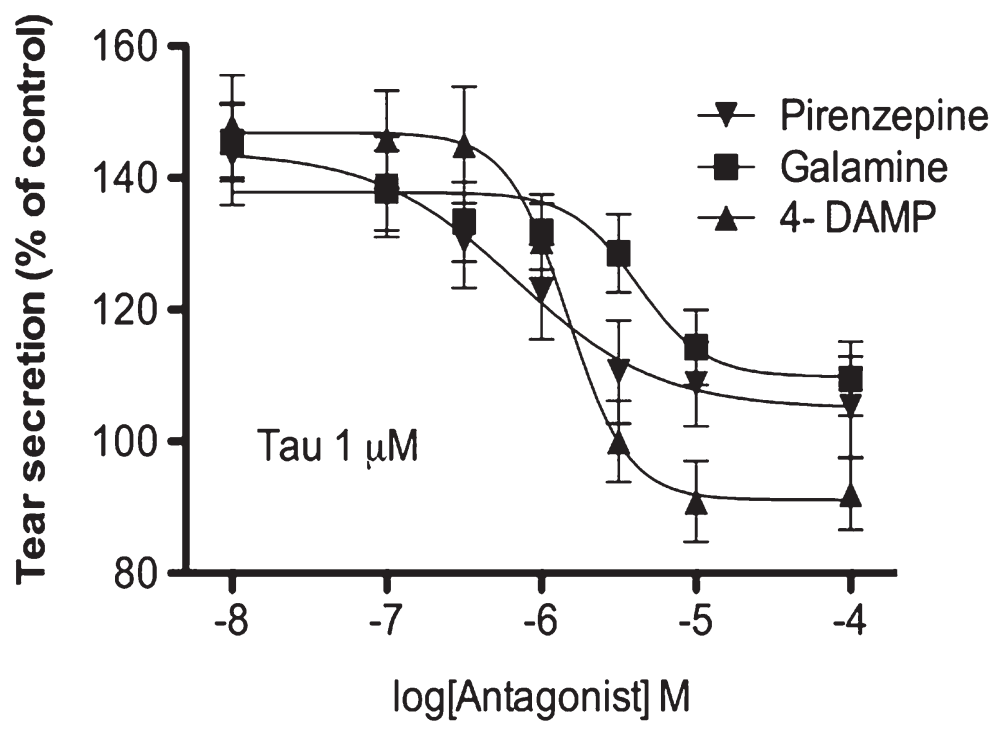

Fig. 3. Antagonism by pirenzepine, galamine, and 4-DAMP (100 $\mu \mathrm{M}, 10 \mu \mathrm{L})$ of the responses produced by tau. A) Effect of the antagonists applied in the absence of any added compound (prepared in saline solution). B) Maximal inhibition. C) Concentration-response course for the antagonists. Values are the mean \pm S.E.M. of eight independent experiments. $* p<0.05, * * p<0.01$, $* * * p<0.001$, with respect to control levels (Two-way ANOVA test with Bonferroni posttests).

antibody PHF-1 could recognize such phosphorylation [31]. Our analyses have shown phospho tau is unable to interact with muscarinic receptors. Interestingly, it has been described that tau antibody targeting the 396/404 region reduces tau pathology [32] and it may be due to a possible block of tau-cell receptor interaction.

Rabbit tear secretion has been widely used as a model where physiological and pharmacological research can be performed [33, 34]. Most of the control of tear secretion is carried out by the autonomic nervous system and therefore tearing is influenced by instillation of drugs that modulate this system. Indeed, the application of carbachol or the instillation of muscarinic antagonists clearly demonstrated the importance of the parasympathetic nervous system in the control of tear secretion. Different substances and stimuli have demonstrated their ability to induce tear secretion $[35,36]$. Good examples are nucleotides and dinucleotides [37]. They are present in tears and when topically applied they stimulate tearing by act- 
ing on purinergic receptors [38]. It is interesting to point out that dinucleotides such as $\mathrm{Ap}_{4} \mathrm{~A}$ which act as a tear inducer, can increase their effect when the indoleamine melatonin is present in tears [39]. This is another example of cross-talk between different substances and may reflect, together with the interaction between tau and muscarinic receptors here described, that tear secretion can be modulated in different manners. It is noteworthy that in both cases, even being so different, the final effect that is obtained is an increase in tear secretion. This fact raises some new questions to take into consideration. On the one hand, the exogenous application of tau, as demonstrated, induces tear secretion. This might be interesting from a therapeutic point of view since one of the most prevalent ocular diseases is dry eye which very often occurs with a lack of tear secretion [40-42]. Interestingly, tau is stimulating muscarinic receptors (see Fig. 1A), therefore inducing tear secretion without the side effects cholinergic agonists can produce when applied to the eye such as myosis, lens opacity, or a blockade lens accommodation [43-47]. So, this may suggest that either tau or its fragment could be used as a treatment for dry eye if no other side effects are found for this protein. However, caution should be taken with this possibility in view of recent data suggesting that tau could be a prionlike protein involved in the spreading of tau pathology. Also it is interesting to point out that although carbachol induces more tearing at a fixed concentration, the concentration-response analysis indicates about one order of magnitude difference between $\mathrm{EC}_{50}$ s, indicating that although carbachol presents a better efficacy (maximal effect), tau is more potent (smaller $\mathrm{EC}_{50}$ ), which totally concurs with previous reports on neural cells cultured [48]. Altogether, we may consider tau and its peptide as partial agonists of muscarinic receptors.

Another important issue is that tau could be present naturally in tears. In this sense, rabbit's eye has been used as a model to test tau function, but it is not known if tau could be present, in a physiological way, in tears. If tau is present in human tears, and its concentration in patients is concomitantly increased as occurs in the CNS, it would be possible to suggest the quantification of this protein in tears as an easy way to detect the pathology in the very early stages of the disease.

In summary, we have demonstrated that tau is able to stimulate muscarinic receptors, mainly M1/M3, in a model in vivo. This interaction may explain in the CNS that the stimulation of these receptors and the concomitant $\mathrm{Ca}^{2+}$ increase triggers the release of more tau explaining the spread of the pathology.

\section{DISCLOSURE STATEMENT}

Authors' disclosures available online (http://www.jalz.com/disclosures/view.php?id=2091).

\section{REFERENCES}

[1] Davies P, Maloney AJ (1976) Selective loss of central cholinergic neurons in Alzheimer's disease. Lancet 2, 1403.

[2] Gomez-Ramos A, Diaz-Hernandez M, Cuadros R, Hernandez F, Avila J (2006) Extracellular tau is toxic to neuronal cells FEBS Lett 580, 4842-4850.

[3] Gomez-Ramos A, Diaz-Hernandez M, Rubio A, MirasPortugal MT, Avila J (2008) Extracellular tau promotes intracellular calcium increase through $\mathrm{M} 1$ and $\mathrm{M} 3$ muscarinic receptors in neuronal cells. Mol Cell Neurosci 37, 673-681.

[4] Iqbal K, Flory M, Khatoon S, Soininen H, Pirttila T, Lehtovirta M, Alafuzoff I, Blennow K, Andreasen N, Vanmechelen E, Grundke-Iqbal I (2005) Subgroups of Alzheimer's disease based on cerebrospinal fluid molecular markers. Ann Neurol 58, 748-757.

[5] Clavaguera F, Bolmont T, Crowther RA, Abramowski D, Frank S, Probst A, Fraser G, Stalder AK, Beibel M, Staufenbiel M, Jucker M, Goedert M, Tolnay M (2009) Transmission and spreading of tauopathy in transgenic mouse brain. Nat Cell Biol 11, 909-913.

[6] Frost B, Jacks RL, Diamond MI (2009) Propagation of tau misfolding from the outside to the inside of a cell. $J$ Biol Chem 284, 12845-12852.

[7] Simon D, Garcia-Garcia E, Royo F, Falcon-Perez JM, Avila J (2012) Proteostasis of tau. Tau overexpression results in its secretion via membrane vesicles. FEBS Lett 586, 47-54.

[8] Saman S, Kim W, Raya M, Visnick Y, Miro S, Jackson B, McKee AC, Alvarez VE, Lee NC, Hall GF (2012) Exosome-associated tau is secreted in tauopathy models and is selectively phosphorylated in cerebrospinal fluid in early Alzheimer disease. J Biol Chem 287, 3842-3849.

[9] Pooler AM, Phillips EC, Lau DH, Noble W, Hanger DP (2013) Physiological release of endogenous tau is stimulated by neuronal activity. EMBO Rep 14, 389-394.

[10] Diaz-Hernandez M, Gomez-Ramos A, Rubio A, GomezVillafuertes R, Naranjo JR, Miras-Portugal MT, Avila J (2010) Tissue-nonspecific alkaline phosphatase promotes the neurotoxicity effect of extracellular tau. J Biol Chem $\mathbf{2 8 5}$, 32539-32548.

[11] Liu L, Drouet V, Wu JW, Witter MP, Small SA, Clelland C, Duff K (2012) Trans-synaptic spread of tau pathology in vivo. PLoS One 7, e31302.

[12] Iba M, Guo JL, McBride JD, Zhang B, Trojanowski JQ, Lee VM (2013) Synthetic tau fibrils mediate transmission of neurofibrillary tangles in a transgenic mouse model of Alzheimer's-like tauopathy. J Neurosci 33, 1024-1037.

[13] de Calignon A, Polydoro M, Suarez-Calvet M, William C, Adamowicz DH, Kopeikina KJ, Pitstick R, Sahara N, Ashe KH, Carlson GA, Spires-Jones TL, Hyman BT (2012) Propagation of tau pathology in a model of early Alzheimer's disease. Neuron 73, 685-697.

[14] Ruskell GL (1969) Changes in nerve terminals and acini of the lacrimal gland and changes in secretion induced by autonomic denervation. Z Zellforsch Mikrosk Anat 94, 261-281.

[15] Ruskell GL (1971) The distribution of autonomic postganglionic nerve fibres to the lacrimal gland in monkeys. $J$ Anat 109, 229-242. 
[16] Dartt DA, Baker AK, Vaillant C, Rose PE (1984) Vasoactive intestinal polypeptide stimulation of protein secretion from rat lacrimal gland acini. Am J Physiol 247, G502-G509.

[17] Dartt DA, Donowitz M, Joshi VJ, Mathieu RS, Sharp GW (1984) Cyclic nucleotide-dependent enzyme secretion in the rat lacrimal gland. J Physiol 352, 375-384.

[18] Hodges RR, Dartt DA (2003) Regulatory pathways in lacrimal gland epithelium. Int Rev Cytol 231, 129-196.

[19] Dartt DA, Botelho SY (1979) Protein in rabbit lacrimal gland fluid. Invest Ophthalmol Vis Sci 18, 1207-1209.

[20] Dartt DA, Knox I, Palau A, Botelho SY (1980) Proteins in fluids from individual orbital glands and in tears. Invest Ophthalmol Vis Sci 19, 1342-1347.

[21] Dartt DA, Moller M, Poulsen JH (1981) Lacrimal gland electrolyte and water secretion in the rabbit: Localization and role of (Na+ + K+)-activated ATPase. J Physiol 321, 557-569.

[22] Ubels JL, Foley KM, Rismondo V (1986) Retinol secretion by the lacrimal gland. Invest Ophthalmol Vis Sci 27, 1261-1268.

[23] Rismondo V, Ubels JL (1987) Isotretinoin in lacrimal gland fluid and tears. Arch Ophthalmol 105, 416-420.

[24] Rismondo V, Ubels JL, Osgood TB (1988) Tear secretion and lacrimal gland function of rabbits treated with isotretinoin. J Am Acad Dermatol 19, 280-285.

[25] Ubels JL, Rismondo V, Osgood TB (1989) The relationship between secretion of retinol and protein by the lacrimal gland. Invest Ophthalmol Vis Sci 30, 952-960.

[26] Pflugfelder SC, Solomon A, Dursun D, Li DQ (2002) Dry eye and delayed tear clearance: "A call to arms." Adv Exp Med Biol 506, 739-743.

[27] Perez M, Valpuesta JM, Medina M, Montejo de Garcini E, Avila J (1996) Polymerization of tau into filaments in the presence of heparin: The minimal sequence required for tautau interaction. J Neurochem 67, 1183-1190.

[28] Gomez-Ramos A, Abad X, Lopez Fanarraga M, Bhat R, Zabala JC, Avila J (2004) Expression of an altered form of tau in Sf9 insect cells results in the assembly of polymers resembling Alzheimer's paired helical filaments. Brain Res 1007, 57-64.

[29] Perez M, Arrasate M, Montejo De Garcini E, Munoz V, Avila $\mathrm{J}$ (2001) In vitro assembly of tau protein: Mapping the regions involved in filament formation. Biochemistry 40, 5983-5991.

[30] van Bijsterveld OP (1969) Diagnostic tests in the Sicca syndrome. Arch Ophthalmol 82, 10-14.

[31] Otvos L, Jr., Feiner L, Lang E, Szendrei GI, Goedert M, Lee VM (1994) Monoclonal antibody PHF-1 recognizes tau protein phosphorylated at serine residues 396 and 404. J Neurosci Res 39, 669-673.

[32] Gu J, Congdon EE, Sigurdsson EM (2013) Two novel tau antibodies targeting the 396/404 region are primarily taken up by neurons and reduce tau pathology. J Biol Chem $\mathbf{2 8 8}$, 33081-33095.
[33] McCanna DJ, Driot JY, Hartsook R, Ward KW (2008) Rabbit models of contact lens-associated corneal hypoxia: A review of the literature. Eye Contact Lens 34, 160-165.

[34] Mircheff AK (1989) Lacrimal fluid and electrolyte secretion: A review. Curr Eye Res 8, 607-617.

[35] Acosta MC, Peral A, Luna C, Pintor J, Belmonte C, Gallar J (2004) Tear secretion induced by selective stimulation of corneal and conjunctival sensory nerve fibers. Invest Ophthalmol Vis Sci 45, 2333-2336.

[36] Crooke A, Guzman-Aranguez A, Peral A, Abdurrahman MK, Pintor J (2008) Nucleotides in ocular secretions: Their role in ocular physiology. Pharmacol Ther 119, 55-73.

[37] Guzman-Aranguez A, Santano C, Martin-Gil A, Fonseca B, Pintor J (2013) Nucleotides in the eye: Focus on functional aspects and therapeutic perspectives. J Pharmacol Exp Ther 345, 331-341.

[38] Pintor J, Peral A, Hoyle CH, Redick C, Douglass J, Sims I, Yerxa B (2002) Effects of diadenosine polyphosphates on tear secretion in New Zealand white rabbits. J Pharmacol Exp Ther 300, 291-297.

[39] Hoyle CH, Peral A, Pintor J (2006) Melatonin potentiates tear secretion induced by diadenosine tetraphosphate in the rabbit. Eur J Pharmacol 552, 159-161.

[40] Barabino S, Chen W, Dana MR (2004) Tear film and ocular surface tests in animal models of dry eye: Uses and limitations. Exp Eye Res 79, 613-621.

[41] Gilbard JP (1985) Topical therapy for dry eyes. Trans Ophthalmol Soc $U K \mathbf{1 0 4}(\mathrm{Pt} 4), 484-488$.

[42] Peral A, Dominguez-Godinez CO, Carracedo G, Pintor J (2008) Therapeutic targets in dry eye syndrome. Drug News Perspect 21, 166-176.

[43] Davidson SI (1974) Systemic effects of eye drops. Trans Ophthalmol Soc $U K$ 94, 487-495.

[44] Doughty MJ, Lyle WM (1992) A review of the clinical pharmacokinetics of pilocarpine, moxisylyte (thymoxamine), and dapiprazole in the reversal of diagnostic pupillary dilation. Optom Vis Sci 69, 358-368.

[45] Jones AL, Keighley JE, Gold W, Good AM (1996) Eye dropsthe hidden poison. Scott Med J 41, 110-112.

[46] Menapace R, Findl O, Kriechbaum K, Leydolt-Koeppl C (2007) Accommodating intraocular lenses: A critical review of present and future concepts. Graefes Arch Clin Exp Ophthalmol 245, 473-489.

[47] Novack GD (1997) Ocular toxicology. Curr Opin Ophthalmol 8, 88-92.

[48] Gomez-Ramos A, Diaz-Hernandez M, Rubio A, DiazHernandez JI, Miras-Portugal MT, Avila J (2009) Characteristics and consequences of muscarinic receptor activation by tau protein. Eur Neuropsychopharmacol 19, 708-717. 